\title{
Impact of Covid-19 on Bottom of the Pyramid Population - An Empirical Study
}

\author{
Keerthan Raj ${ }^{1} \&$ P. S. Aithal ${ }^{2}$ \\ College of Management \& Commerce, Srinivas University, Mangalore - 575 001, India. \\ ${ }^{1}$ OrchidID:0000-0003-0190-4610, E-mail:2keerthanraj@gmail.com \\ ${ }^{2}$ Orchid ID: 0000- 0002-4691-8736, E-mail: psaithal@gmail.com
}

Area/Section: Business Management.

Type of the Paper: Empirical Research.

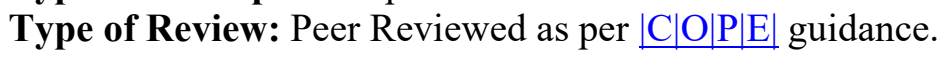

Indexed in: OpenAIRE.

DOI: $\underline{\text { http://doi.org/10.5281/zenodo.4417864 }}$

Google Scholar Citation: $\underline{\text { IJMTS. }}$

\section{How to Cite this Paper:}

Keerthan Raj \& Aithal P. S. (2020). Impact of Covid-19 on Bottom of the Pyramid Population - An Empirical Study. International Journal of Management, Technology, and Social Sciences (IJMTS), 5(2), 380-388. DOI: http://doi.org/10.5281/zenodo.4417864

International Journal of Management, Technology, and Social Sciences (IJMTS) A Refereed International Journal of Srinivas University, India.

(C) With Author.

\begin{abstract}
(c) (1) (8)
This work is licensed under a Creative Commons Attribution-Non-Commercial 4.0 International License subject to proper citation to the publication source of the work.

Disclaimer: The scholarly papers as reviewed and published by the Srinivas Publications (S.P.), India are the views and opinions of their respective authors and are not the views or opinions of the SP. The SP disclaims of any harm or loss caused due to the published content to any party.
\end{abstract}




\title{
Impact of Covid-19 on Bottom of the Pyramid Population - An Empirical Study
}

\author{
Keerthan Raj ${ }^{1} \&$ P. S. Aithal ${ }^{2}$ \\ College of Management \& Commerce, Srinivas University, Mangalore - 575 001, India. \\ 1OrchidID:0000-0003-0190-4610,E-mail:2keerthanraj@gmail.com \\ ${ }^{2}$ Orchid ID: 0000- 0002-4691-8736, E-mail: psaithal@gmail.com
}

\begin{abstract}
The Covid-19 pandemic has triggered a lot of studies on its impact, the way in which countries managed or coped with the issues arising out of the pandemic, and so on. While countries had several lessons to learn in terms of speed and thrust on leapfrogging digital capabilities and also creating a super-fast crisis access team in health considering the intensity and surge in numbers that needed critical care globally, the fact of the matter is that it is the low income category of the population of every country that had to suffer the most hardships. In this paper, the researchers study a set of this base of the pyramid population through a mixed approach, to understand the severity and impact that the pandemic and its associated restrictions and government measures had on the population.
\end{abstract}

Keywords: Covid-19, Bottom of the pyramid, Pandemic

\section{INTRODUCTION:}

The Covid-19 pandemic that gripped the world since November 2019 has been a huge disrupter. It has displaced large number of people from the comfort of daily livelihoods, economies have been set back by a couple of years, projected returns have not been sacrificed for revised pessimistic goals. At the initial stages of the breakout, it was never fathomed that most countries would be sent to month long lockdowns leading to severe impact on industrial production, stagnation of sectors and economic upheaval. The world has faced pandemics before as well, most notable was the influenza pandemic of 1918, largely known as the 'Spanish flu'. During this pandemic, it is estimated that 50-100 million people died, which is about $5 \%$ of the world's population. More than half a billion people were infected. However, in spite of all the development in technology and in the information age, the world is no better prepared to face a pandemic than it was a century ago. The only upside is that there are more ways to trace due to internet of things, scientists know more on how to isolate and countries are better equipped to face larger numbers and deal with the pandemic crisis [1]. Unlike Covid-19, the Spanish Flu killed people in their $20 \mathrm{~s}$ and $30 \mathrm{~s}$, their peak productive years. Countries reacted to the situation in almost the same manner by the following tracing, tracking, quarantining, and advocating sanitization and social distancing measures and other restrictions by and large to contain the spread.

On the one hand, there is a great fear of the virus and on the other hand, severe government restrictions were placed by almost all countries. However, the Spanish Flu had a much milder impact on economic activity since the modern day lockdowns were not observed in the $1918 \mathrm{~s}$, the measures were limited to social distancing and wearing of masks etc. due to lack of adequate date and repositories, the St. Louis Fed report opined that it was the retail businesses that suffered heavy setbacks. However, at that point in time it was a fear of the virus among the people, more than government restrictions, was a major reason for self imposed restrictions then and likely the biggest driver of loss of revenue then [2]. Another cause could be the structure of the economy a century ago. The industry was dominated by manufacturing and agriculture which are seemingly less vulnerable to the pandemic than today's dominant space occupied by services and retail sectors. Also, interestingly, since it was the phase of World War I, the government had instructed factories not to close down completely to meet the basic dire needs of society. These decisions affected the spread of the epidemic but the impact on the economic output was reduced, and as the economy slowly started shifting back towards productive gains, the flu had gone. A couple of factors that make the corona virus's economic damage more severe and longer than the Spanish Flu are that today's businesses have become completely globalized, international supply chains have spread across the globe. Learning from the lockdowns and impact on 
manufacturing countries may offshore less production in the future knowing the risk in the days to come fearing the second wave and a third, and this is a costly and painful transition or course correction for companies. Businesses today are highly leveraged as against the scenario one hundred years back, and this debt would combine with the economic ill effects of the pandemic to cause companies to look at a balance-sheet recession.

\section{OBJECTIVES:}

The objective of this paper is primarily two fold -

1. To understand the impact of the Covid-19 pandemic on the low income earning population.

2. To identify the correlation between occupations of the largely low income population and the impact of the pandemic.

3. To understand further factors defining comfort and access in the poor population and the significance of the impact on future decisions.

\section{METHODOLOGY:}

A mixed method was adopted of qualitative data for collection of information to design the key constructs for the study. The constructs were identified on the basis of informal in-depth discussion with people belonging to the low income category as per published data. The key variable so identified has then been used to construct a structured questionnaire to illicit response. A sample of 60 respondents was considered through a questionnaire in vernacular language. The study is a mixed method approach, based on two sources of data- a qualitative approach of gathering requisite information on antecedents and then designing the questionnaire and the subsequent analysis of quantitative data. Mixed methods research is an emerging methodological movement with a growing body of trans-disciplinary literature. Prominent research methodologists/authorities from across discipline fields are emerging and guiding the commentary and the movements' momentum [3]. Studies in which qualitative and quantitative methods are integrated make them valuable. Mixed method studies can capitalize on the strengths of both quantitative and qualitative approaches [4]. Mixed method research is being used increasingly by the researches and most of the published mixed method researches have been employed to find answers which needs deeper understanding of the target population under consideration. The combination of qualitative and quantitative findings provides findings which were not possible with any single approach [5].

\section{BACKGROUND:}

\subsection{BOP Market:}

The bottom or base of the pyramid refers to the segment of people who live on less than $\$ 2$ per day or with purchasing power parity (PPP) of less than $\$ 1500$ per year. Management thinkers C K Prahalad and Stuart Hart in their work in 2002, which later was elaborated by Prahalad in his book 'The Fortune at the Bottom of the Pyramid: Eradicating Poverty through Profits' (2005) emphasised this and has garnered more attention from corporations and thinkers likewise. They theorized that there exists a huge, untapped, consumer market at the bottom of the economic pyramid and companies by engaging in this market can earn significant profits by selling products and services to the poor, the poor were a large market to consider and since the term "bottom of the pyramid" has been in use to refer to this section of population, over time the word bottom has found replacement to better sounding terms as "base" of the economic pyramid. In the backdrop of a lack of clear categorization of the low income population management thinkers, economists, global consulting firms and government institutions have tried to answer what should out lie the categorization of 'poor' and overtime this has been used to arrive at parameters to differentiate between that 'haves' and the 'have nots' and what constitutes as 'have'. This bottom of the pyramid (BOP) approach propounded by C. K. Prahalad and Stuart L. Hart in their book 'The Fortune at the Bottom of the Pyramid' (2002) used a 4-tiered pyramid to represent the global way in which wealth is distributed and the capacity to generate income. At the top of the world economic pyramid are 75 to 100 million affluent Tier I consumers from around the world. At the centre of the pyramid, in Tiers 2 and 3, are poor customers in developed nations and the rising middle classes in developing countries. Further, they categorised 4 billion people in Tier 4 i.e. at the bottom of the pyramid. Their annual per capita income based on purchasing power parity in U.S. dollars is less than 
$\$ 1,500$, the minimum considered necessary to sustain a decent life. For well over a billion people roughly one-sixth of humanity per capita income is less than $\$ 1$ per day [6].

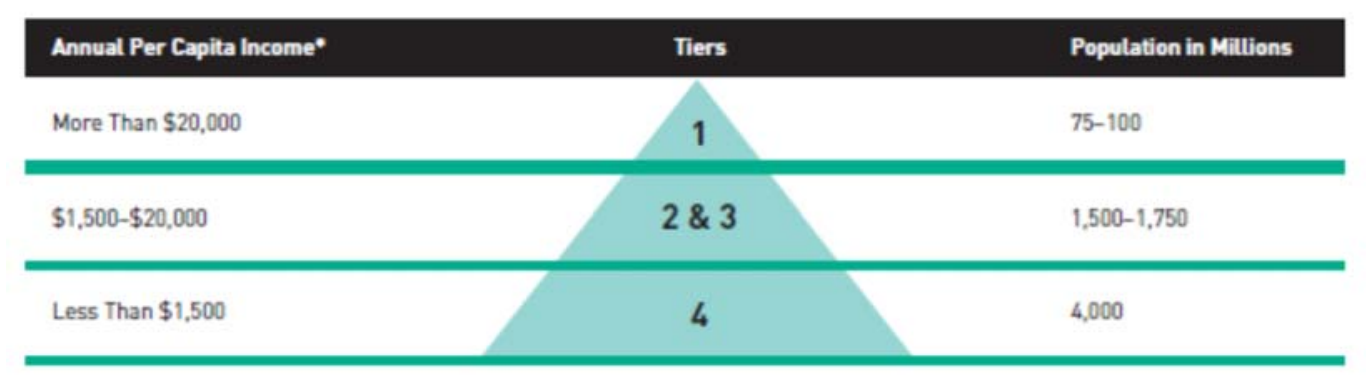

- Blacos un purchasing pawer sariay in Uss

Fig. 1: World Economic Pyramid Source: U.N. World Development Reports (Adapted from Prahalad \& Hart, 2002)

The measurement of the poor population in India - The base of the pyramid a large percentage of the population and market in India. The McKinsey report published in 2005 stated that 1.05 billion people were BOP, i.e., on an average this segment was living on an annual household income of less than INR 200,000 per year or 16,667 per month. It is obvious that in urban India the cost of living is higher; here BOP is categorized as the population having an annual household income of less than INR 3, 00,000. This translates to less than INR 25,000 monthly household income. In rural India, an annual household income of less than INR 1, 60,000 or monthly household income of INR 13,333 is considered as BoP. Vast economic growth has propelled advancements and a fast growing middle class, the report however, states that BOP still stands at 78\% of India's population or 997 million people in 2015 [6]. However, the Ministry of Rural Development has over time looked at various criteria and parameters for measuring poverty in India [7]. The fundamental problem is a clear definition of whom and on that basis of what means do you categorize an individual as poor. Many government benefit schemes hinges on this categorization to make more income and subsidies to be made available to this sector of society. Due to widespread criticism of Tendulkar Committee report and approach adopted by it, as it was stated that over time there was changes in the aspirations of people, Rangarajan Committee was set up in 2012. This Committee submitted its report in June 2014. It reverted to the practice of categorizing India into rural and urban poverty line baskets and deriving state-level rural and urban estimates from these. The Rangarajan committee recommended separate consumption baskets for rural and urban areas which include food items that ensure recommended calorie, protein \& fat intake as well as non-food items like clothing, education, health, housing and transport. This committee raised the daily per capita expenditure to Rs 47 for urban and Rs 32 as against the earlier per capita expenditure of Rs 32 and Rs 26 respectively at 2011-12 prices. A per month per capita consumption expenditure of Rs. 972 in rural areas and Rs. 1407 in urban areas was recommended as the poverty line at the all India level. However, the use of Consumption Expenditure Surveys Poverty line estimation in India has been based on the consumption expenditure and not on the income levels due to difficulties in assessing incomes of selfemployed people, daily wage labourers, etc, large fluctuations in income due to seasonal factors, additional side incomes as well as data collection difficulties in largely rural and informal economy of India. Since households may be able to access credit markets or household savings and thereby smooth their consumptions to some degree, consumption expenditures are considered to be a better method to provide a better basis.

The Ministry of Rural Development (MoRD) appointed an expert committee chaired by Dr. N. C. Saxena to propose a new methodology for identifying BPL households. The committee proposed a radical departure from previous BPL Censuses and recommended a three-fold classification of households into "excluded", "automatically included" and "others". Based on Saxena Committee's recommendations, in 2011, the MoRD launched the Socioeconomic and Caste Census (SECC) - a doorto-door enumeration across both rural and urban India collecting household-level socio-economic data. Its objective was not to replace the poverty line, but to provide 'information regarding the socioeconomic condition, and education status of various castes and sections of the population' and 'enable 
households to be ranked on their socio economic status' to identify households that live below the poverty line. The Census captured data on households - individual particulars, housing, deprivation, employment, income, assets/amenities, and land ownership. This census 2011 ranked households in three categories:

(a) Automatically Excluded: Households meeting exclusion criteria - any of the 13 assets and income based parameters are automatically excluded from welfare benefits;

(b) Automatically Included: Households satisfying inclusion criteria - any one of the 5 acute social destitution parameters are automatically included for welfare benefits;

(c) Others: "Others" are ranked on the basis of 7 indicators of deprivation and would, resources permitting be eligible for welfare benefits.

SECC 2011 captured data on socio economic status of 17.97 crore rural households which has resulted in automatic exclusion of 7.07 crore (39.36\%) of households as not poor, automatic inclusion of 0.16 crore $(0.91 \%)$ households as poorest of the poor, and grading of deprivation of 8.72 crore $(48.54 \%)$ of rural households. Unlike the BPL Censuses, SECC-2011 allowed for the first time to track the deprivation of households and address gaps effectively with focus on multi-dimensionality of poverty. Being outside the Census Act, it provides a rare opportunity to know the specific deprivation of each household. The Sumit Bose Committee (2017) recommended using SECC 2011 data to identify beneficiaries for all centrally sponsored, central and state government schemes as far as possible. The Government has used SECC data for identification of beneficiary households while implementing its social welfare programmes.

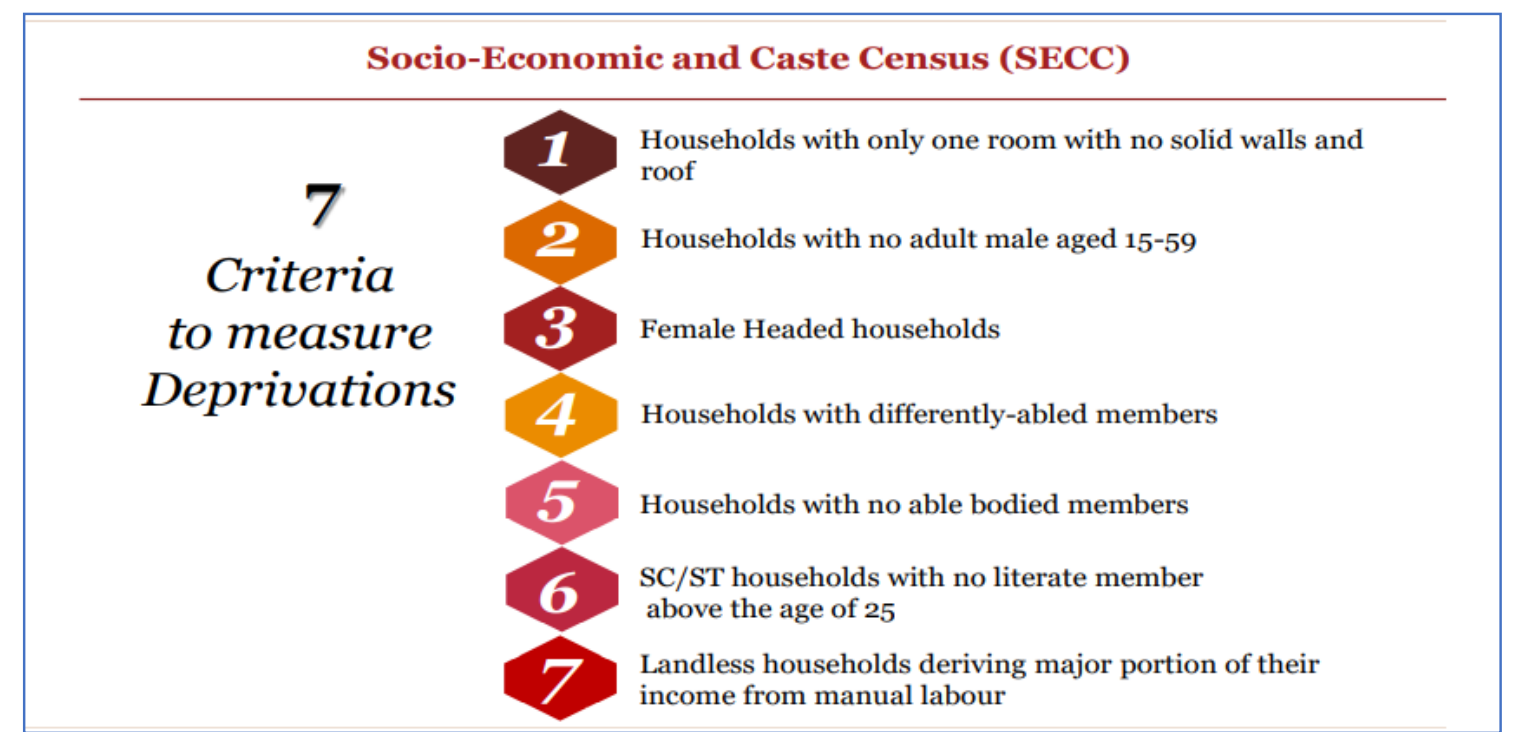

Fig. 2: Socio - Economic and Caste Census (SECC) to measure multi dimensional poverty (Source: MoRD, Report, 2017)

\subsection{International Indices to Measure Poverty:}

In recent years, international research agencies and institutions have, based on evidence suggested a transformational change in the rate of poverty decline in India. Both in terms of income and decline of chronic poverty as also in terms of multi-dimensional poverty, the performance of India over the last two decades has attracted global attention. World Bank defines poverty as deprivation in well-being comprising many dimensions. It includes low incomes and the inability to acquire the basic goods and services necessary for survival with dignity. Out of 17 Sustainable Development Goals (SDGs), to which India is committed, the first two are "ending poverty in all forms and hunger". SDG is by 2030 to reduce at least by half the proportion of men, women and children of all ages living in poverty in all its dimensions according to national definitions. India has committed itself to achieving the Sustainable Development Goals (SDGs); government has charted out and is working closely to address the issue of poverty. The goal commits all countries who have signed to eliminate poverty according to the common international poverty line of $\$ 1.25$ per person per day (at 2005 Purchasing Power Parity or PPP) and 
cutting it in half "according to national definitions" (goals 1.1 and 1.2, respectively). The UN's 2030 Agenda for Sustainable Development has reaffirmed the importance of multi-dimensional approaches to poverty eradication that would need to look beyond economic deprivation at other facets of poverty. Various international efforts to measure poverty along with implications for India are listed herein: a) Global Multi Dimensional Poverty Index (MPI) Launched in 2010 by the United Nations Development Program (UNDP) and the Oxford Poverty and Human Development Initiative (OPHI), the MPI is a measure of multidimensional poverty covering more than 100 developing countries. It goes beyond income as the sole indicator for poverty and tracks deprivation across three dimensions and 10 indicators as indicted below:

(i) Education: Number of years of schooling and child enrolment

(ii) Health: Child mortality and nutrition

(iii) Standard of living: Electricity, flooring, drinking water, sanitation, cooking fuel and assets

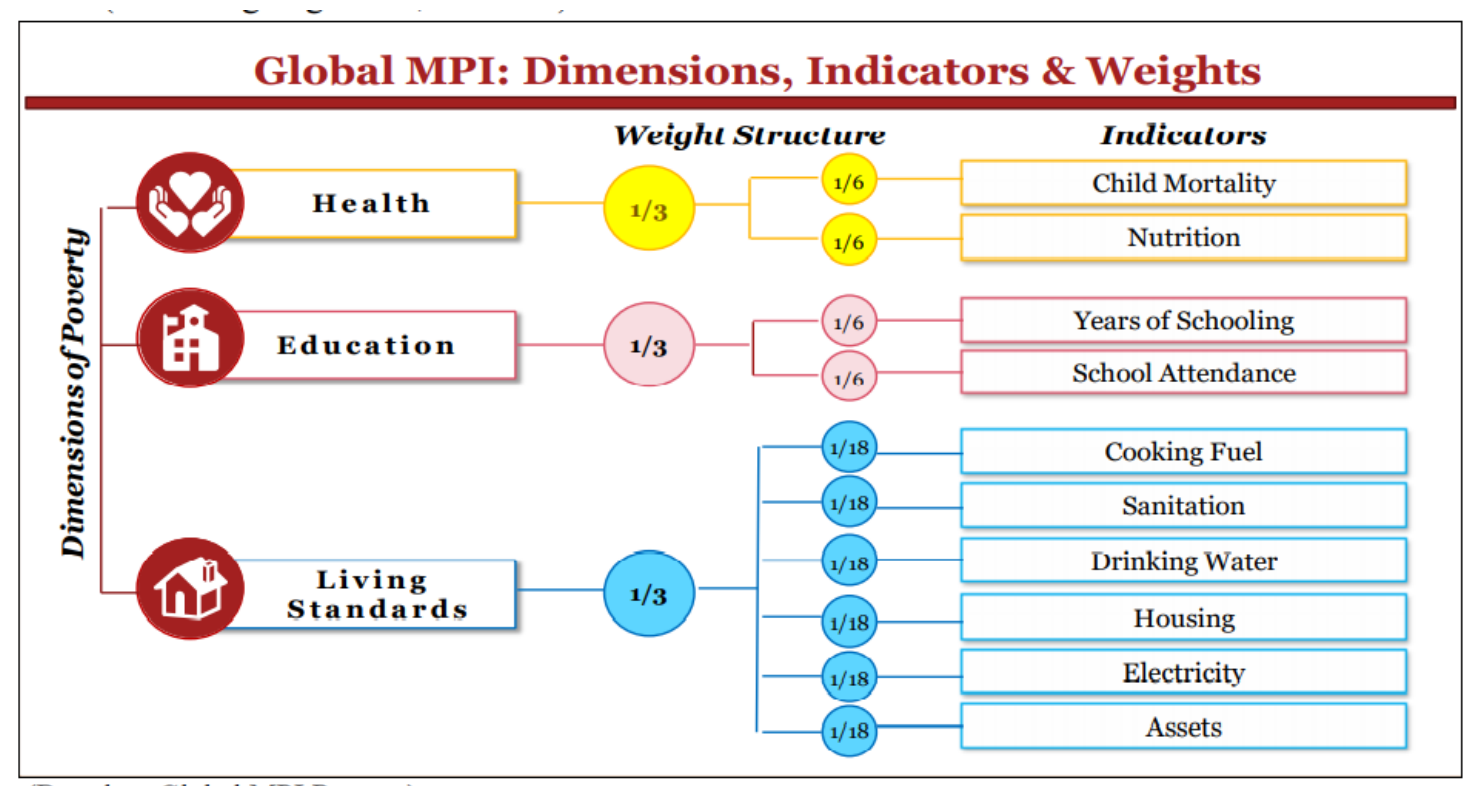

(Based on Global MPI Reports)

Fig. 3: Global Poverty Indices

Global MPI 2020 Report indicates that India has been ranked at the 62nd position from amongst 107 countries with an MPI score of 0.123 and $27.9 \%$ of population identified as multi-dimensionally poor, the number was $36.8 \%$ for rural and $9.2 \%$ for urban India. There were wide variations across states.

World Bank Poverty Line - Presently, the World Bank has defined extreme poverty as living on less than $\$ 1.90$ a day, measured in 2011 purchasing power parity prices. But, the measure of poverty through headcount would undermine the ability to capture the intensity of poverty - individuals with consumption levels marginally below the poverty line are counted as being poor just as individuals with consumption levels much further below the poverty line. World Bank has developed the 'poverty gap index' as an alternative way of measuring poverty that measures the intensity of poverty, by calculating the amount of money required by a poor household in order to reach the poverty line. In other words, it calculates the income or consumption shortfall from the poverty line. The "poverty gap index" is denied as the mean shortfall in income or consumption from the International Poverty Line (\$1.90 a day in 2011 international dollars) counting the non-poor as having zero shortfall, expressed as a \%age of the poverty line 13 . Poverty gap for India is reported at $4.3 \%$ in 2011 down from $20 \%$ in 1977, as per the World Bank collection of development indicators, compiled from officially recognized sources [8]. We can see a marked positive correlation between the incidence of poverty and the intensity of poverty. Over the last few decades, priorities have shifted with development in India. We see a larger number of people benefitting from the schemes of the government and the inspirational levels of the poor are higher, the poor seek betterment in education, health, housing, skills and consumption, and not merely minimum food and shelter. Hence, poverty is not just about basic food and clothing but looks at living 
standards -sanitation, housing, piped water, electricity, education, health, and jobs. Hence, categorization on the frugal minimum needs of human society is not adequate for categorization of poverty, poverty line assessment if it were to be done presently cannot be based on minimum expenditure on subsistence basket of food and nutrition alone, as done in the past. Also, the corona pandemic has brought to fore, as observed in the largest slum dwelling of the world, Dharavi in, Mumbai, where we saw marked increase of the virus spread, it underscores the criticality of certain "essentials" to be considered to be out of poverty certain things being - quality healthcare and access and affordability of the same, education and awareness, water and sanitation facilities, adequate nutrition, and the need for living spaces where social distancing can be practiced. A safety net for loss of income where the family could sustain over months without daily wages which was proven difficult during the corona pandemic. The World Bank has classified India as a lower middle-income country and the corresponding poverty line would be PPP \$3.2 (2011 prices), which translates into roughly a consumption level of Rs 75 per person per day [8].

\section{DATA ANALYSIS AND HYPOTHESES TESTING:}

For the purpose of this study the researchers identified key variables that were critical to creating an ease of living in the poor population. The loss of job, reduction in the family expenses, hardships to meet day to day monetary needs, due to covid-19 pandemic was studied to identify an association with occupation, marital status, education qualification, and income.

Hypothesis 1: There is significant association between occupation and loss of work due to lockdown restrictions.

Hypothesis 2: There is significant association between education levels and loss of work due to lockdown

Hypothesis 3: There is significant association between marital status and loss of work due to lockdown. Hypothesis 4: There is significant association between income and loss of work due to lockdown. While we can see from the below table that there is no significant association between occupation, marital status and education levels to loss of work due to lockdown. So irrespective of education, occupation and marital status was a leveller but income was disrupted and Hypothesis 4 is accepted.

There is significance association between income and Loss of work due to lockdown at $1 \%$ as the $p$ value is less $0.01, \mathrm{H}_{1}$ is accepted. Lockdown and restrictions reduce your family income is associated with Income level as the $\mathrm{p}$ value is less than $0.05 . \mathrm{H}_{1}$ is accepted.

Impact of pandemic on job and family income is also associated with income level of the respondents as $\mathrm{p}$ value is less than $0.05 ., \mathrm{H}_{1}$ is accepted and there is association between marital status and stability in the present job and income status as the $\mathrm{p}$ value is less than $0.05 . \mathrm{H}_{1}$ is accepted

Table 1: Chi-square/ Fisher Exact Test and Statistics

\begin{tabular}{|c|c|c|c|c|}
\hline Covid Effect & Occupation & Educational & Marital Status & Income \\
\hline $\begin{array}{l}\text { Loss of work due } \\
\text { to lockdown }\end{array}$ & $\begin{array}{l}\text { FETV: } 1.737 \\
\mathrm{P}>0.05 \\
\mathrm{H}_{0} \text { is Accepted. }\end{array}$ & $\begin{array}{l}\text { FETV: } 1.115 \\
\mathrm{P}>0.05 \\
\mathrm{H}_{0} \text { is Accepted. }\end{array}$ & $\begin{array}{l}\text { FETV: } 0.833 \\
\mathrm{P}>0.05 \\
\mathrm{H}_{0} \text { is Accepted }\end{array}$ & $\begin{array}{l}\text { FETV:9.422 } \\
P<0.01 \\
H_{1} \text { is Accepted }\end{array}$ \\
\hline $\begin{array}{l}\text { lockdown and } \\
\text { restrictions } \\
\text { reduction in } \\
\text { family income }\end{array}$ & $\begin{array}{l}\text { FETV: } 1.532 \\
\mathrm{P}>0.05 \\
\mathrm{H}_{0} \text { is Accepted. }\end{array}$ & $\begin{array}{l}\text { FETV:1.592 } \\
\mathrm{P}>0.05 \\
\mathrm{H}_{0} \text { is Accepted. }\end{array}$ & $\begin{array}{l}\text { FETV:0.513 } \\
\mathrm{P}>0.05 \\
\mathrm{H}_{0} \text { is Accepted }\end{array}$ & $\begin{array}{l}\text { FETV:6.756 } \\
\mathrm{P}<0.05 \\
\mathrm{H}_{1} \text { is Accepted }\end{array}$ \\
\hline $\begin{array}{l}\text { Impact of } \\
\text { pandemic on job } \\
\text { and family } \\
\text { income. }\end{array}$ & $\begin{array}{l}\text { FETV: } 1.619 \\
\mathrm{P}>0.05 \\
\mathrm{H}_{0} \text { is Accepted. }\end{array}$ & $\begin{array}{l}\text { FETV:2.791 } \\
\mathrm{P}>0.05 \\
\mathrm{H}_{0} \text { is Accepted. }\end{array}$ & $\begin{array}{l}\text { FETV:0.238 } \\
\mathrm{P}>0.05 \\
\mathrm{H}_{0} \text { is Accepted }\end{array}$ & $\begin{array}{l}\text { FETV:5.253 } \\
\mathrm{P}<0.01 \\
\mathrm{H}_{1} \text { is Accepted }\end{array}$ \\
\hline
\end{tabular}

Hypothesis 5: There is significance correlation between gender with respect to impact of pandemic on job and family income. 
Table 2 : Mann-Whitney U test and Statistics

\begin{tabular}{|l|l|l|l|}
\hline Variable & Single & Married & $\mathbf{Z}$ and $\mathbf{P}$ value \\
\hline $\begin{array}{l}\text { Stability in the Present } \\
\text { job and Income status }\end{array}$ & 7.83 & 16.35 & $\mathrm{Z}=1.921$ \\
& & $\begin{array}{l}\mathrm{P}<0.05 \\
\mathrm{H}_{1} \text { is accepted at } 5 \%\end{array}$ \\
\hline
\end{tabular}

Mann Whitney $U$ test value shows that there is a significance mean difference between gender with respect to Stability in the Present job and Income status. As the $p$ value is less than 0.05 of variance. This is due to the fact that the female respondents' occupation was as house maid category and such other odd jobs of housekeeping and cleaning, during the pandemic as mobility around city was restricted and employers had placed restrictions in engaging the services of visiting house maids the gender and impact of income was significant. A fallout of this could also be understood on society being able to provide quickly alternate earning odd job opportunities for the male gender in India whereas it is not so easily possible for the female gender.

Another important basic statistical percentage analysis was observed that when a question of the further effects of the corona pandemic is forecasted and some similar job losses are assumed, the respondents of half the number of respondents still wanted to continue in Mangalore and not return back to hometown. The lure of high income earning opportunity in the short term span of 10-15 years of their lives and the opportunity to provide better education, means and quality of life to their family was important to them.

Table 3: Respondents keen to return to hometown or continue to be employed in the city in case of continued pandemic effects or similar such disruptions

\begin{tabular}{|l|l|r|r|}
\hline \multicolumn{1}{|c|}{} & \multicolumn{1}{|c|}{ Frequency } & Percent \\
\hline Options & 15 & 50.0 \\
& $\begin{array}{l}\text { Continue in } \\
\text { Mangalore }\end{array}$ & 10 & 33.3 \\
\cline { 2 - 5 } & Return to hometown & 5 & 16.7 \\
\cline { 2 - 5 } & Not sure & $\mathbf{3 0}$ & $\mathbf{1 0 0 . 0}$ \\
\cline { 2 - 5 } & Total & & \\
\end{tabular}

\section{DISCUSSION:}

The study was significant through the mixed method, as a lot of information was able to be gathered from the low income BOP population, the fuel for the migratory work force is the growth of urban cities and job opportunities. As seen from published statistics, in 2001, as per the National Report published by the Ministry of Housing and Urban Poverty Alleviation about $23.5 \%$ of urban households were slum dwellers. This percentage had decreased to $17 \%$ by 2011 although the total number of households living in slums had gone up from 10.5 million in 2001 to 13.75 million in 2011. Greater Mumbai, Delhi NCR and Kolkata have no less than $42 \%$ to $55 \%$ of their urban population in slums. This corona pandemic as per study has created a disproportionate effect especially among low-income households in most of the countries. This is especially due to the fact that low income population occupations are most always concentrated in the informal sectors, and hence are more vulnerable to job losses, have lower financial savings, and have less access to healthcare. The IMF's fiscal monitor report, October 2020, has significantly brought about comparative studies in both the developed and developing economies which conclude that the pandemic is impacting the economically more vulnerable, like younger workers and women the most. The segment of population employed in small and medium enterprises or those in unorganized sector or informally employed are more vulnerable to job loss. It also pointed out that the pandemic would "exacerbate pre-existing trends" in the context of income inequality. Mega-cities are where the majority of urban poverty growth happens. As the researchers have found in their analysis also, the lure of jobs and increasing their income as opposed to staying back in their hometowns where many families have to live off small tracts of land cultivation and there is very little other employment possibilities with attractive wages brings the population to cities. But, in times of such lockdowns brought about by the pandemic the very question of quality of life and the extent to which increased 
income is able to provide a succour to alleviated quality of live is a question in point. However, this segment shows resilience in their approach to be able to stay there, build back and continue thereon to reach the small milestones they set for themselves. Majority of the respondents in the study were employed as security persons in apartment complexes, some were having food stalls, selling street food, some were into construction workers, so a cross section, but all impacted negatively and some more so with job and loss of income. But, with such pandemics their livelihood gets back to stage one by having to dip into saved money to eke out a living and sets them back by a few years. Significant to note that, what constitutes the mindset to consider 'out of poverty' is a relative term and is constantly changing for this segment of population.

\section{CONCLUSION:}

Over time, India will need to adjust to the new reality of the so called BOP sector, where incomes may increase overtime and affordability may rise but within this growth they still are a part of a lower middle- income segment, where poverty just changes it guise to still mean a lack of income to take advantage of the opportunities thrown up by a growing economy offering innumerable consumerist attractions even thing basic frugal necessities may be available adequately. Further, deprivations in different areas are positively correlated with one another. Deprivation in a pucca dwelling may not necessarily be correlated with means to good education, as cities shrink in size certain qualifications to be considered out of poverty may never be available to the population such as access to sanitation and clean water and healthcare may need to be taken up by public policy.

\section{REFERENCES:}

[1] Raj, K., \& Aithal, P. S. (2020). The Post COVID-19 World: Efforts Needed to Build Back a More Resilient Society. International Journal of Case Studies in Business, IT, and Education (IJCSBE), 4(1), 88-93.

[2] Raj, K., \& Aithal, P. S. (2018). Sustainable development in India 2.0 with reference to the BOP perspective. International Journal of Applied Engineering and Management Letters (IJAEML), (2018), 2(2), 87-97.

[3] Leech, N. L. \& Onwuegbuzie, A. J. (2006). A typology of mixed methods research designs, Quality and Quantity, 42(2), 265-275.

[4] Östlund, U., Kidd, L., Wengström, Y., \& Rowa-Dewar, N. (2011). Combining qualitative and quantitative research within mixed method research designs: a methodological review. International journal of nursing studies, 48(3), 369-383.

[5] Bryman, A. (2007). Barriers to integrating quantitative and qualitative research. Journal of mixed methods research, 1(1), 8-22.

[6] Raj, K., \& Aithal, P. S. (2018). Literature Review of Impact of Branding on Base of the Pyramid Markets with Special Reference to India. International Journal of Applied Engineering and Management Letters (IJAEML), 2(1), 43-63.

[7] Datt, G., Ravallion, M., \& Murgai, R. (2020). Poverty and Growth in India over Six Decades. American Journal of Agricultural Economics, 102(1), 4-27.

[8] Ackland, R., Dowrick, S., \& Freyens, B. (2013). Measuring global poverty: Why PPP methods matter. Review of Economics and Statistics, 95(3), 813-824.

[9] Madhushree, L. M., Bhuvana, R., \& Aithal, P. S. Impact of COVID-19 on Redefining the Services of Educational Institutions using Ubiquitous Technology. International Journal of Management, Technology, and Social Sciences (IJMTS), 5(2), 266-282.

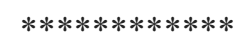

